\title{
ALTERATIONS IN SOME BIOCHEMICAL PARAMETERS IN CATTLE AFFECTED WITH FOOT AND MOUTH DISEASE IN DAKAHLIA GOVERNORATE, EGYPT
}

\author{
Eman A. Kamal ${ }^{1}$, Mohamed F. Salama ${ }^{2}$, Ahmed Elgamal ${ }^{1}$, Nabil Abo Heakal ${ }^{3}$ \\ ${ }^{1}$ Animal Health Research Institute, Mansoura Provincial Laboratory, Mansoura, Egypt. \\ ${ }^{2}$ Department of Biochemistry, Faculty of Veterinary Medicine, Mansoura University, Mansoura 35516, Egypt. \\ ${ }^{3}$ Department of Physiology, Faculty of Veterinary Medicine, Mansoura University, Mansoura 35516, Egypt.
}

\section{ABSTRACT}

This study was carried out to evaluate the changes in serum biochemical parameters during foot and mouth disease (FMD) viral infection, so blood samples were collected from different farms in Dakahlia Governorate during the outbreak of the disease in 2016. Blood samples were collected after complete clinical and physical examination of twenty five cattle; their ages were ranging from 1-2 years and divided into two groups as follows: 15 cattle were showing the clinical signs of the disease and 10 cattle were clinically healthy (control group). The obtained results showed a significant increase in glucose level $(P<0.01)$, non-esterified fatty acids $($ NEFA) $(P<0.001)$, beta hydroxyl butyric acid $(B H B A)(P<0.001)$ and lipase enzyme $(P<0.01)$ in infected cattle compared to control group. On the other hand, serum insulin concentration and amylase were significantly lower in blood of infected cattle than control group $(P<0.001)$ and $(p<0.01)$ respectively.

From the obtained results it could be concluded that FMD infection in cattle is associated with hyperglycemia, hypoinsulinemia and ketosis.

Key words: FMD; NEFA; BHBA; Ketosis; Insulin; Cattle.

\section{INTRODUCTION}

Foot and mouth disease (FMD) is an economically important disease as it causes severe losses in the livestock industry. Moreover, the disease leads to high morbidity in adult animals, a sharp decrease in milk production, weight losses, reproduction problems, death in young animals, and treatment cost and the time spent in the management of sick animals (Belsham, 2005).

FMD is an acute highly contagious viral disease that affects all cloven-hoofed animals (Alexandersen and Mowat, 2005). The disease is caused by viruses of Picornaviridae family which belong to genus Aphthovirus.
FMD virus has seven distinct serotypes namely Asia 1, SAT1, SAT2, SAT3, C, A, O (Domingo et al., 2003).

The clinical signs of the disease are foamy salivation, fever, blisters (vesicles), erosions and ulcers on dental pad, gum, lips, tongue, feet, and also on teats. Moreover, lameness is evident in animals with foot lesions and it may be the only sign in FMD-infected sheep. Some strains of the FMD virus can cause necrosis of heart muscle that may result in death before the development of lesions (Lubroth, 2002). FMDV is usually observed in the herds of non-vaccinated cattle; however, its existence in the vaccinated animals is 
indicative of vaccination failure (Abubakar et al., 2014).

Animals that are infected with FMDV usually show ulcers on tongue and off food to avoid pain; therefore, they have negative energy balance (NEB) that leads to massive mobilization of non-esterified fatty acids (NEFA) from the adipose tissue (Bell, 1997), which results from the induction of hormone sensitive lipase release and subsequent lipolysis (Melendez et al., 2009).

Incomplete oxidation of NEFA in the liver leads to formation of ketone bodies $(\beta$ hydroxyl butyrate, acetoacetate and acetone) with subsequent ketosis (Drackley et al. 2005). NEFA and BHBA are the most common indicators for evaluation of lipid mobilization and ketosis (González, 2011).

Ketosis is a metabolic disorder which occurs in adult cattle. It occurs when the demand of energy is more than energy intake (Grummer, 1993). Ketosis in cattle is still not completely understood, but it needs the combination of adipose mobilization from intestine and a high glucose demand. Therefore, the description of ketosis includes high serum level of ketone bodies and NEFA (Oetzel, 2004).

NEFAs prompt phosphorylation of insulin receptor substrate 1 (IRS-1) on serine residues that leads to a reduction in insulininduced tyrosine phosphorylation of IRS-1, which is important for normal activation of insulin signaling cascade (LeMarchandBrustel et al., 2003).

The biochemical alterations associated with FMD viral infection in cattle are not clearly understood. Therefore, the current study aimed to examine the effect of FMDV on some biochemical parameters in infected cattle.

\section{MATERIAL AND METHODS}

\subsection{Animals}

This study was carried out on twenty five cattles from different farms in Dakahlia Governorate, Egypt. Animals were assigned into two groups: the first one was consisting of 15 cattle which showed the clinical characteristic of FMD. The second group (control group) was consisted of 10 cattles that were apparently clinically healthy. The animals were thoroughly examined and were free from parasitic infestation.

\subsection{Samples}

Blood samples were collected from cattle of both groups from the jugular vein either into fluoride containing tubes for estimation of blood glucose or plain tubes for serum separation. Serum was collected from the plain tubes by centrifugation at 10 minutes at 3000 rpm, and serum samples were then stored at $-20^{\circ} \mathrm{C}$ until used to determine some biochemical parameters.

\subsection{Biochemical analysis}

Glucose was determined according to Trinder, (1969), insulin according to Chevenne et al, (1998), NEFA according to Smith and Wilson, (2006), BHBA according to Young D.S (2000), lipase according to Steer A.C.et al., (2009) and amylase according to Winn-Deen,E.S.,et al.,(2005).

\subsection{Statistical analysis}

Data were statistically analyzed by using student's t-test by using GraphPad prism 
(GraphPad Software, Incorporated, La Jolla, $\mathrm{CA}$, USA) and were presented as mean \pm standard error of mean. $P$ values of $\leq 0.05$ were considered to be statistically significant (Scendecor GW, and Cochran WG, 1969).

\section{RESULTS}

FMD-infected cattle showed typical clinical signs including foamy salivation, ulcers on the dental pad, and recumbency (Figure 1).

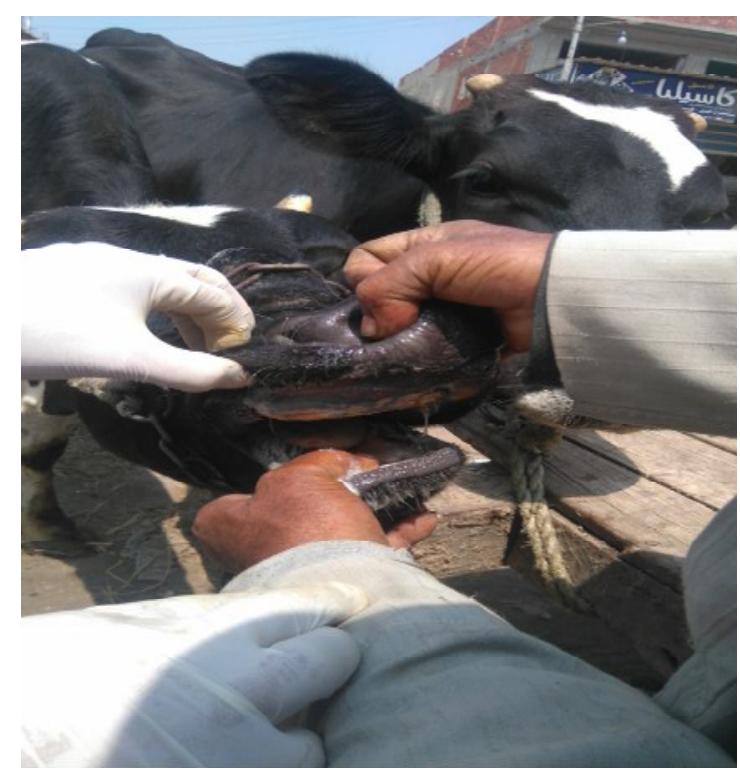

Results of the biochemical variables in control and FMD-infected animals are presented in table (1).

The data showed a significant increas $(p<0.05)$ in NEFA, BHBA- concentrations as well as serum glucose level and lipase activity in FMD-infected cattle compared to that of the control group. On the other hand, there was a significant reduction $(\mathrm{p}<0.05)$ in the serum insulin level and amylase activity in the diseased animals compared to the control.

Figure (1). Clinical signs of FMD-infected cattle. The observed clinical signs included:

ulcers on the dental pad (a) and foamy salivation and recumbency (b) in FMDinfected cattle.

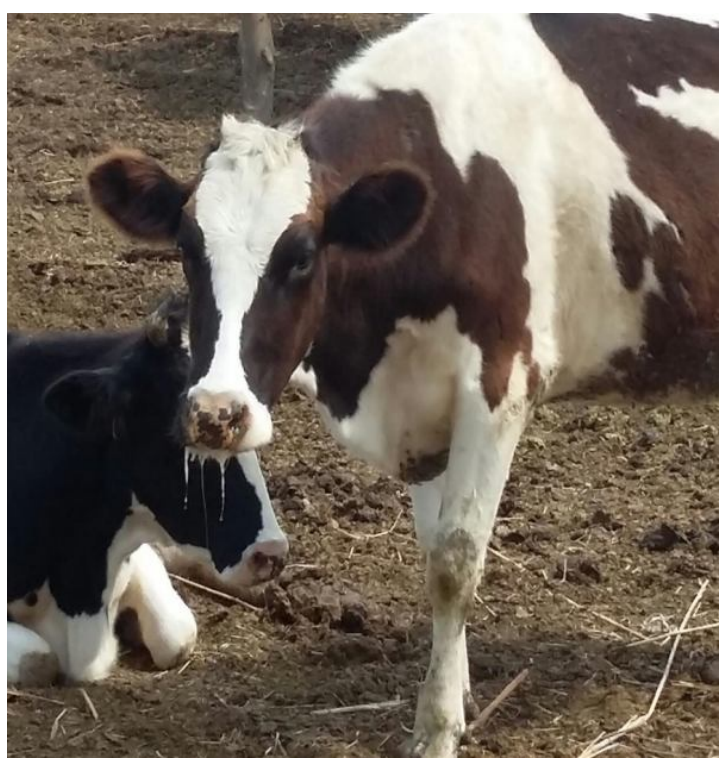


Table (1). Serum biochemical parameters in control and FMD-infected cattle (mean \pm SE).

\begin{tabular}{|c|c|c|}
\hline Parameter & $\begin{array}{c}\text { Healthy animals } \\
(\mathbf{n = 1 0})\end{array}$ & FMD infected animals (n=15) \\
\hline NEFA $(\mathrm{mmol} / \mathrm{L})$ & $0.28 \pm 0.02$ & $1.28 \pm 0.14^{* * *}$ \\
\hline BHBA $(\mathrm{mmol} / \mathrm{L})$ & $0.87 \pm 0.01$ & $3.00 \pm 0.16^{* * *}$ \\
\hline Glucose $(\mathrm{mg} / \mathrm{dl})$ & $48.67 \pm 1.6$ & $68.2 \pm 3.8^{* *}$ \\
\hline Lipase $(\mathrm{U} / \mathrm{L})$ & $29.5 \pm 7.4$ & $71.2 \pm 8.7^{* *}$ \\
\hline Insulin $(\mu \mathrm{LU} / \mathrm{ml})$ & $10.61 \pm 0.49$ & $15.9 \pm 0.68^{* * *}$ \\
\hline Amylase $(\mathrm{U} / \mathrm{L})$ & $25.5 \pm 2.4$ & $13.5 \pm 1.8^{* *}$ \\
\hline
\end{tabular}

${ }^{* *, * * *}$ denotes statistical significant differences compared to control group.

\section{DISCUSSION}

The current study aimed to investigate biochemical alterations associated with FMD infection in cattle. Our results showed hyperglycemia and hypoinsulinemia in FMD infected cattle. Hyperglycemia is a common finding in animals affected by systemic diseases due to stresses (Yeotikar et al., 2003; Gokce et al., 2004 and Paalberg et al., 2002). The reason behind increased glucose level and decreased insulin concentration could also be due to the destruction of islets of Langerhans of pancreatic $\beta$-cells subsequent to FMD viral infection (Sutmoller et al. 2003). Moreover, it was suggested that low insulin concentrations may be due to alterations in pancreatic $\beta$-cell functions developed during the clinical course of FMD (Barboni, 1966).

Hyperglycemia and diabetes may occur during FMD viral infection in cattle by two different mechanisms; the direct destruction pancreatic $\beta$-cells by the virus or by the autoimmune response that develops against the virus (Clark, 2003).
The increased NEFA concentration in the FMD-infected cattle could be attributed to reduction in feed intake with subsequent increase in energy demand that leads to negative energy balance (NEB) and compensation by mobilization of NEFA from adipose tissues (Baird, 1982). Increased fat mobilization is evident in our study by the observed increase in lipase in FMD-infected cattle (table, $\mathbf{1})$.

Increased BHBA concentrations in FMDinfected cattle is indicative of excessive fat mobilization and subsequent ketosis. Excessive fat mobilization is usually accompanied by a marked formation of acetyl-coenzyme $\mathrm{A}$ and the tricarboxylic acid cycle cannot fully metabolize fatty acids. Therefore, acetyl coenzyme $\mathrm{A}$ is converted to acetoacetate which is then reduced to BHBA by BHBA dehydrogenase or spontaneously decarboxylated into acetone (Baird, 1982; Brumby et al., 1975).

Part of the mobilized body fat will be converted to ketones in the liver which leads to increase the concentration of ketones in the blood. Once the metabolic and endocrine 
systems are unable to regulate NEB, ketone body production increases rapidly, and ketosis becomes unavoidable (Herdt, 2000).

High BHBA concentrations of (more than $1 \mathrm{mmol} / \mathrm{L}$ ) (table, 1) was accompanied by higher insulin resistance and higher NEFAs concentrations were correlated with a lower insulin secretion significantly (Kerestes M., et al., 2009). That could also explain the observed hypoinsulinemia in our present study.

In the present study, we showed that FMD infection in cattle is associated with a decrease in serum amylase levels. Krehbiel et al., (1995) reported that blood amylase activity is used as a clinical laboratory test in diagnosis of acute pancreatitis. On the other hand, (Mohamed et al. 2003) found that the serum amylase level in cows with chronic pancreatitis remains normal.

Patients with very low serum insulin showed a reduction in serum amylase. A similar decrease in serum amylase was observed in diabetic rats that was reversed by insulin injection (Patel et al., 2006). Pancreas weight was significantly decreased in animals which have elevated blood glucose and low plasma insulin levels compared to the healthy control also diabetic animals eat less and moreover, they produce less digestive enzymes, especially amylase (Singh,J., E,etal.2004).

\section{CONCLUSION}

This study suggests that FMD virus has a deleterious effect on the pancreatic cells that is evident by the decrease in serum insulin level and amylase activity with subsequent hyperglycemia. Moreover, FMD infection is also associated with ketosis as evidenced by increased serum BHBA levels.

\section{REFERENCES}

Abubakar, M., Jamil, A., \& Ali, Q. (2014). An evaluation of foot-and-mouth disease outbreak in relation to vaccination in a herd of cattle and buffaloes. Research Journal for Veterinary Practitioners, 2(2), 28-9.

Alexandersen, S., \& Mowat, N. (2005). Footand-mouth disease: host range and pathogenesis. In Foot-and-Mouth Disease Virus (pp. 942).

Baird, G. D. (1982). Primary ketosis in the high-producing dairy cow: clinical and subclinical disorders, treatment, prevention, and outlook. Journal of Dairy Science, 65(1), 1-10.

Barboni, E., Mannocchio, I., \& Asdrubali, G. (1966). The development of diabetes mellitus in cattle experimentally infected with virus of foot and mouth disease. Vet. Ital, 17, 339-368.

Bell, A. W., \& Bauman, D. E. (1997). Adaptations of glucose metabolism during pregnancy and lactation. Journal of mammary gland biology and neoplasia, 2(3), 265-278.

Belsham, G. J. (2005). Translation and replication of FMDV RNA. In Footand-Mouth Disease Virus (pp. 4370).Springer Berlin Heidelberg.

Brumby, P. E., Anderson, M. A. L. C. O. L. M., Tuckley, B. R. I. A. N., Storry, J. E., \& Hibbit, K. G. (1975). Lipid metabolism in the cow during starvation-induced ketosis. Biochemical Journal, 146(3), 609-615.

Chevenne D, Letailleur, A, Trivin Fand Porquet D. (1998): Effect of hemolysis on the concentration of 
insulin determined by RIA IRMA. Clin Chem., 44,354-6.

Clark, Z. (2003). Diabetes mellitus in a 6month-old Charolais heifer calf. The Canadian Veterinary Journal, 44(11), 921.

Domingo, E., Escarmís, C., Baranowski, E., Ruiz-Jarabo, C. M., Carrillo, E., Núñez, J. I., \& Sobrino, F. (2003). Evolution of foot-and-mouth disease virus. Virus research, 91(1), 47-63.

Drackley, J. K., Dann, H. M., Douglas, N., Guretzky, N. A. J., Litherland, N. B., Underwood, J. P., \& Loor, J. J. (2005). Physiological and pathological adaptations in dairy cows that may increase susceptibility to periparturient diseases and disorders. Italian Journal of Animal Science, 4(4), 323-344.

Gökçe, G., Gökçe, H. İ., Günes, V., Erdogan, H. M., \& Çitil, M. (2004). Alterations in some haematological and biochemical parameters in cattle suffering from foot-and-mouth disease. Turkish Journal of Veterinary and Animal Sciences, 28(4), 723-727.

González, F. D., Muiño, R., Pereira, V., Campos, R., \& Benedito, J. L. (2011). Relationship among blood indicators of lipomobilization and hepatic function during early lactation in high-yielding dairy cows. Journal of veterinary science, 12(3), 251-255.

Grummer, R. R. (1993). Etiology of lipidrelated metabolic disorders in periparturient dairy cows. Journal of Dairy Science, 76(12),3882-3896.

Herdt TH (2000). Ruminant adaptation to negative energy balance. Influences on the etiology of ketosis and fatty liver. Veterinary Clinics of North America Food Animal Practice 16: 215-230.
Kerestes, M., Faigl, V., \& Kulcsar, M. (2009). Periparturient insulin secretion and whole-body insulin responsiveness in dairy cows showing various forms of ketone pattern with or without puerperal metritis. Domestic Animal Endocrinology, 37(4), 250-261.

Krehbiel, C. R., Britton, R. A., Harmon, D. L., Wester, T. J., \& Stock, R. A. (1995). The effects of ruminal acidosis on volatile fatty acid absorption and plasma activities of pancreatic enzymes in lambs. Journal of animal science, 73(10), 3111-3121.

Le Marchand-Brustel, Y., Gaul, P., Gremeaux, T., Gonzalez, T., Barres, R., \& Tanti, J.F. (2003). Fatty acidinduced insulin resistance: role of insulin receptor substrate 1 serine phosphorylation in the retroregulation of insulin signalling. Biochemical Society Transactions, 31, 1152-1156.

Lubroth, J. (2002). Foot-and-mouth disease: A review for the practitioner. Veterinary Clinics of North America: Food Animal Practice, 18(3), 475-499.

Melendez, P., Marin, M. P., Robles, J., Rios, C., Duchens, M., \& Archbald, L. (2009). Relationship between serum nonesterified fatty acids at calving and the incidence of periparturient diseases in Holstein dairy cows. Theriogenology, 72(6), 826-833.

Mohamed, T., Sato, H., Kurosawa, T., Oikawa, S., \& Nitanai, A. (2003). Ultrasonographic imaging of experimentally induced pancreatitis in cattle. The Veterinary Journal, 165(3), 314-324.

Oetzel, G. R. (2004). Monitoring and testing dairy herds for metabolic 
disease. Veterinary Clinics: Food Animal Practice, 20(3), 651-674.

Paarlberg, P. L., Lee, J. G., \& Seitzinger, A. H. (2002). Potential revenue impact of an outbreak of foot-and-mouth disease in the United States. Journal of the American Veterinary Medical Association, 220(7), 988-992.

Patel, R., Pariente, J. A., Martinez, M. A., Salido, G. M., \& Singh, J. (2006). Effect of Insulin on AcetylcholineEvoked Amylase Release and Calcium Mobilization in Streptozotocin-Induced Diabetic Rat Pancreatic Acinar Cells. Annals of the New York Academy of Sciences, 1084(1), 58-70.

Scendecor GW, and Cochran WG, Statistical Methods. $6^{\text {th }}$ ed. Ames: Iowa State University Press; 1969. pp. 59-65.

Singh, J., E. Adeghate, S. Aparico, et al. 2004. Exocrine pancreatic insufficiency in diabetes mellitus. Int. J. Diabetes Metab. 12: 35-43.
Smith and Wilson. Free Fatty Acids and Atherosclerosis. J Clin Endocrinol Steer A.C.et al., Clin.Vac. immunology, 16,172 (2009).

Stockham, S. L., \& Scott, M. A. (2013). Fundamentals of veterinary clinical pathology. John Wiley \& Sons.

Sutmoller, P., Barteling, S. S., Olascoaga, R. C., \& Sumption, K. J. (2003). Control and eradication of foot-and-mouth disease. Virus research, 91(1), 101-144.

Trinder P. (1969):Colorimetric determination of glucose Ann. Clin. Biochem, 6, 24.

Winn-Deen,E.S.,et al., development of a direct assay for a amylase, Yeotikar, P. V., Bapat, S. T., Bilolikar, S. C., \& Kulkarni, S. S. (2003). Metabolic profile of healthy cattle and cattle affected by foot-and-mouth disease. Veterinary record, 153(1), 1920.

Young D.S., Effect of drugs on clinical Lab. Test, $5^{\text {th }}$ Ed. AACC Press(2000).. 


\section{المالخص العربي \\ بعض التغيرات الكيميائية الحيوية في الماشية المصابة بمرض الحمي القلاعية \\ في محافظة الدقهلية - مصر}

إيمان أحمد كمال' ، محمد فودة سلامة"، أحمد الجمل'، نبيل أبو هيكل'

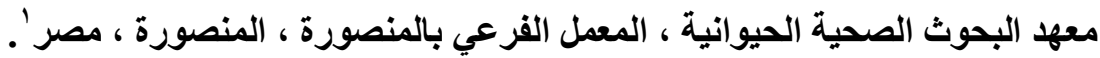

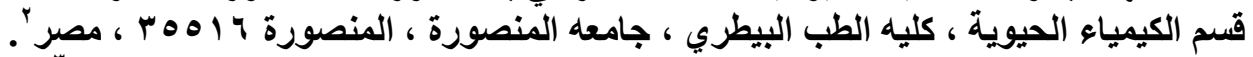

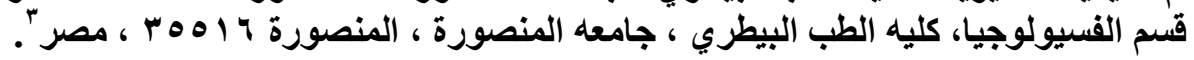

أجريت هذه الاراسة لمعرفة التغيرات في المعايير البيوكيميائية في مصل دم الأبقار المصابة بمرض الحمى

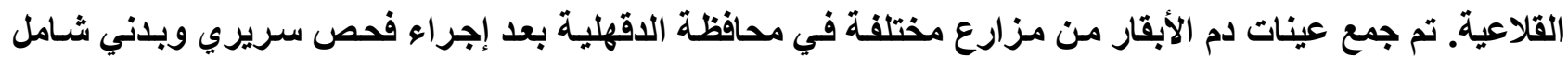

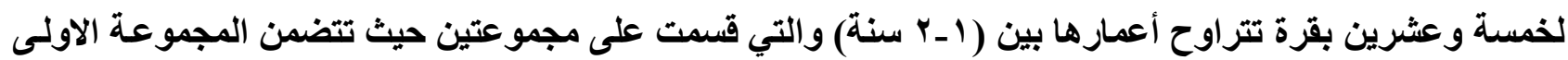

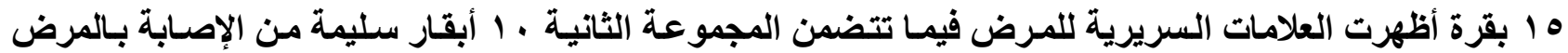

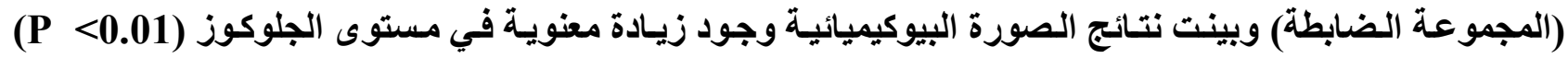

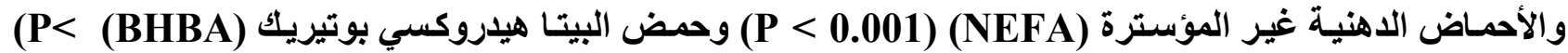

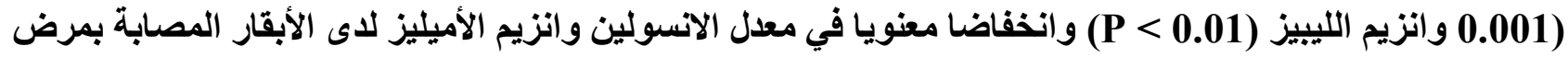

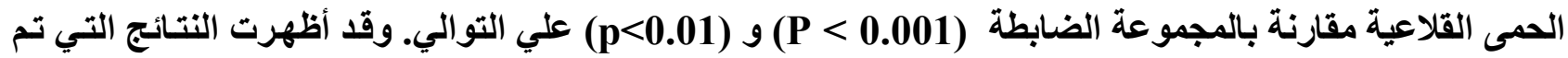

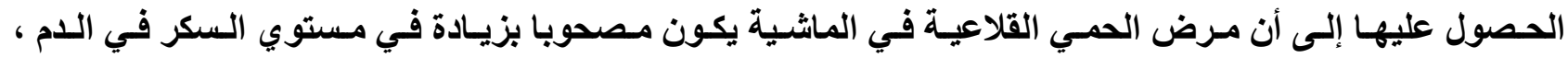
وانخفاض مستوي الانسولين في الام ، والكيتوزيس. 